\title{
SINDROMA FOSTER KENNEDY
}

\author{
Reinne Natali Christine ${ }^{1}$, Nicholas Dwiki Tanong ${ }^{1}$ \\ Departemen Ilmu Penyakit Mata Fakultas Kedokteran Universitas Kristen Indonesia \\ Jakarta
}

\begin{abstract}
Abstrak
Pendahuluan: Sindrom Foster Kennedy merupakan penyakit mata yang secara klasik melibatkan atrofi saraf optik ipsilateral dengan neoplasma intrakranial dengan papilledema kontralateral yang terjadi bersamaan. Sedikitnya 37 kasus telah didokumentasikan secara lengkap antara tahun 1909 dan 1989. Ini adalah kasus yang sangat langka karena tidak semua massa intrakranial akan bermanifestasi sebagai Sindrom Foster Kennedy.
\end{abstract}

Tujuan: Melaporkan kasus Sindroma Foster Kennedy akibat massa supratentorial

Laporan Kasus: Seorang wanita berusia empat puluh tahun datang ke Klinik Mata RS UKI Jakarta dengan riwayat 3 bulan penurunan penglihatan secara perlahan tanpa disertai nyeri mata. Dia tidak memiliki gejala mata lainnya dan tidak memiliki riwayat penyakit mata sebelumnya. Pasien mengeluh sakit kepala terus menerus yang lebih berat di pagi hari sehingga pasien minum analgetik secara teratur untuk mengurangi sakit kepala. Pada pemeriksaan fisik didapatkan tanda vital dalam batas normal penurunan berat badan sekitar lima kilogram dalam dua bulan dan anosmia. Ketidakstabilan emosional ditemukan. Pasien memiliki riwayat penggunaan kontrasepsi hormonal sejak dua belas tahun yang lalu dan tidak ada riwayat penyakit yang sama di keluarganya. Pada pemeriksaan ketajaman penglihatan adalah 6/6 pada mata kanan dan 1/60 pada mata kiri. Pada pupil terdapat defek aferen relatif. Segmen anterior normal. Pada pemeriksaan fundus dilatasi, ditemukan adanya pembengkakan pada papil diskus optik kanan dan pada papil optik kiri pucat. Computed tomography (CT) kepala dan orbit menunjukkan massa supratentorial di regio frontotemporal kiri. Pemeriksaan perimetri menunjukkan skotoma sentral dan depresi mata yang berat. Pasien dirujuk ke tim bedah saraf untuk diperiksa, dan disarankan untuk melakukan debulking pada lesi.

Kesimpulan: Pada kasus Sindroma Foster Kennedy yang disebabkan oleh adanya massa intrakranial, diperlukan kerjasama dalam penatalaksanaan dengan departemen lain seperti bedah saraf. Diagnosis dini dengan reseksi bedah dapat mencegah kerusakan penglihatan lebih lanjut dan bersifat "life saving"

Keyword : sindroma foster kennedy, massa supratentorial 


\begin{abstract}
Introduction: Foster Kennedy syndrome is a rare condition that classically involves optic nerve atrophy ipsilateral to an intracranial neoplasm with concomitant contralateral papilledema. As few as 37 cases have been completely documented between 1909 and 1989 . It was a very rare case because not all of intracranial mass would be manifestated as Foster Kennedy Syndrome
\end{abstract}

Objective: To report a case of Foster Kennedy Syndrome due to supratentorial mass

Case: A forty year old woman presented at Eye Clinic UKI hospital Jakarta with a 3-month history of gradual, painless, unilateral deterioration of her vision. She had no other ocular symptoms and no previous ocular history. She also complained about persistent headache which worsened at the morning and took regular analgetic to reduced headache. Systematic head toe examination revealed within normal limit with weight loss about five kilograms in last two months and anosmia. Emotional lability was found. Patient have had a history of hormonal contraception since twelve years ago and no history of same illness in her family. On examination, visual acuity was $6 / 6$ (logMar 0$)$ in the right eye and finger counting (logMar 1.78) in the left eye. There was a relative afferent papillary defect (RAPD). Pupils were round and reactive to light. The anterior segments were normal. On dilated fundus examination, she was found to have a grossly swollen right optic disc and a pale left optic disc. Computed tomography $(C T)$ of the head and orbits revealed a supratentorial mass at left frontotemporal region. Perimetry Kinetic examination revealed central scotoma and severe depression of the eye. The patient was referred to the neurosurgical team for further examination, and debulking of the lesion was recommended.

Conclusion: In case of Foster Kennedy syndrome due to intracranial mass, early diagnosis and collaboration with neurosurgeon with subsequent surgical resection may prevent further visual deterioration and life saving

Keyword: Foster Kennedy syndrome, supratentorial mass 


\section{Pendahuluan}

Sindroma Foster Kennedy dengan nama lain Sindroma Basal-Frontal atau Sindroma Gowers-Paton Kennedy adalah suatu sindroma yang ditimbulkan karena adanya lesi di intrakranial baik berupa tumor maupun non-tumor, serta ditandai dengan gambaran papil atrofi pada sisi yang sesuai lesi dan papil edema pada sisi kontralateral lesi. Lesi tersebut umumnya berada pada daerah frontal basal atau sekitar sayap sphenoid dan menyebabkan penekanan pada saraf optik. Gambaran lain yang bisa dijumpai adalah pada pemeriksaan lapang pandangan bisa didapatkan adanya skotoma sentral disisi papil yang mengalami atrofi serta adanya pelebaran bintik buta dan konstriksi perifer di sisi yang mengalami papil edema. ${ }^{1}$

Gambaran papil edema yang bersifat unilateral seperti pada Sindroma Foster Kennedy memang jarang, hanya terdapat pada 8\% kasus dibanding papiledema bilateral. Jumlah laporan kejadian kasus ini hanya 37 kasus di seluruh dunia dalam kurun waktu 1909 - 1989. ${ }^{2}$ Beberapa keadaan baik itu yang berlokasi intraorbita maupun intraokuler dapat memiliki gambaran yang serupa seperti neuropati optik iskemik, edema papil pada kejadian iridocyclitis unilateral, edem papil pada CRVO, drusen pada papil unilateral ataupun pada hyperopic pseudoneuritis. ${ }^{2,3}$

Penyebab utama sindroma Foster Kennedy $68 \%$ adalah tumor lobus frontalis dan meningioma dari cekungan olfaktori dan sayap sphenoid. Sisanya 32\% disebabkan oleh kondisi non tumor seperti arteriosklerosis, optochiasmatic arachnoiditis dan aneurisma karotis. ${ }^{2}$

Walaupun angka kejadian kasus dengan gambaran funduskopi yang menunjukkan sindroma Foster Kennedy sangat kecil , namun kondisi ini sering kurang diperhatikan karena gambaran papiledema yang dominan pada satu sisi menyebabkan perhatian dokter mata terhadap perubahan minimal pada mata sebelahnya menjadi berkurang. Kondisikondisi yang menyebabkan timbulnya gambaran fundus yang asimetris atau gambaran edema papil unilateral seharusnya dipertimbangkan sebagai suatu diagnosis banding. Selain itu seorang dokter ahli mata perlu mengevaluasi hasil pemeriksaan oftalmologis secara serial untuk mengetahui diagnosis dan terapi yang tepat. Mengingat sebagian besar penyebab tumor ini adalah lesi intrakranial yang memerlukan pemeriksaan dan penanganan interdisiplin baik dari oftalmologi, neurologi, bedah saraf dan radiologi.

\section{Laporan Kasus}

Nyonya $\mathbf{J}$, seorang pasien perempuan umur 40 tahun domisili di Jakarta. Datang ke polimata RSU UKI pada 9 mei 2019 dengan keluhan kedua mata terasa buram sejak 4 bulan yang lalu. Tidak ada mata merah, mata berair maupun nyeri pada gerak kedua mata.

Dari anamnesis diketahui bahwa pasien juga merasa sering pusing dan perlahan-lahan penglihatan jauh semakin berkurang dan aktivitas pasien sebagai seorang pedagang. Tiap pagi kepala terasa pusing dan kadang mual menyertai keluhan. Dalam 2 minggu belakangan ini pasien juga merasakan keluhan lain yaitu lubang hidung kiri seperti tersumbat dan tidak dapat mencium bau seperti lubang hidung sebelahnya.(perbaiki kata)

Berat badan pasien dirasakan berkurang dan pasien menjadi lebih sensitif secara emosional dan mudah marah. Pasien merupakan akseptor $\mathrm{KB}$ dengan riwayat penggunaan injeksi KB tiga bulanan selama 18 tahun dan sudah berhenti menjadi akseptor sekitar 6 bulan sebelum ke Rumah 
Sakit. Semenjak penglihatan terganggu pasien mulai mengurangi aktivitas hingga akhirnya pasien memutuskan untuk berobat ke polimata RSU UKI pada 9 mei 2019.

Tidak ada riwayat penyakit sistemik (hipertensi, diabetes mellitus, kardiovascular, hiperkolesterol, gangguan koagulasi darah), tidak ada riwayat trauma, tidak ada riwayat kejang, maupun kebiasaan merokok. Pada riwayat keluarga tidak didapatkan riwayat penyakit sistemik, tumor atau keganasan.

Pada pemeriksaan sistemik didapatkan kesadaran komposmentis, status gizi baik, tekanan darah 130/80, frekuensi nadi $80 \mathrm{kali} / \mathrm{menit}$, frekuensi napas 20 kali/menit, dan suhu badan afebris.

Hasil pemeriksaan mata kanan didapatkan tajam penglihatan $6 / 10$ dengan koreksi kacamata $\mathrm{S}+1,00$ menjadi 6/6 E. Palpebra dan konjungtiva tenang, kornea jernih, kamera okuli anterior dalam dan jernih, pupil bulat, sentral, diameter $4 \mathrm{~mm}$, reflek cahaya direk dan indirek positif. Lensa jernih, vitreus jernih, tampak edema diskus optikus, tampak perdarahan kecilkecil di tepi papil, vena tampak melebar dan agak hitam, reflek fovea cemerlang, tekanan intra okular $13 \mathrm{mmHg}$. Pergerakan bola mata bebas ke segala arah dan tidak ada nyeri.
Hasil pemeriksaan mata kiri didapatkan tajam penglihatan 1/60 dengan persepsi warna dan cahaya baik dan tidak dapat dikoreksi dengan kacamata. Palpebra tenang, konjungtiva tenang, kornea jernih, kamera okuli anterior dalam dan jernih, pupil bulat, central, diameter $4 \mathrm{~mm}$, reflek cahaya direk positif dan indirek negatif. Lensa jernih, vitreus jernih, papil pucat, kaliber pembuluh darah retina tampak menyempit, reflek fovea redup, tekanan intra okular $10 \mathrm{mmHg}$. Pergerakan bola mata bebas ke segala arah.

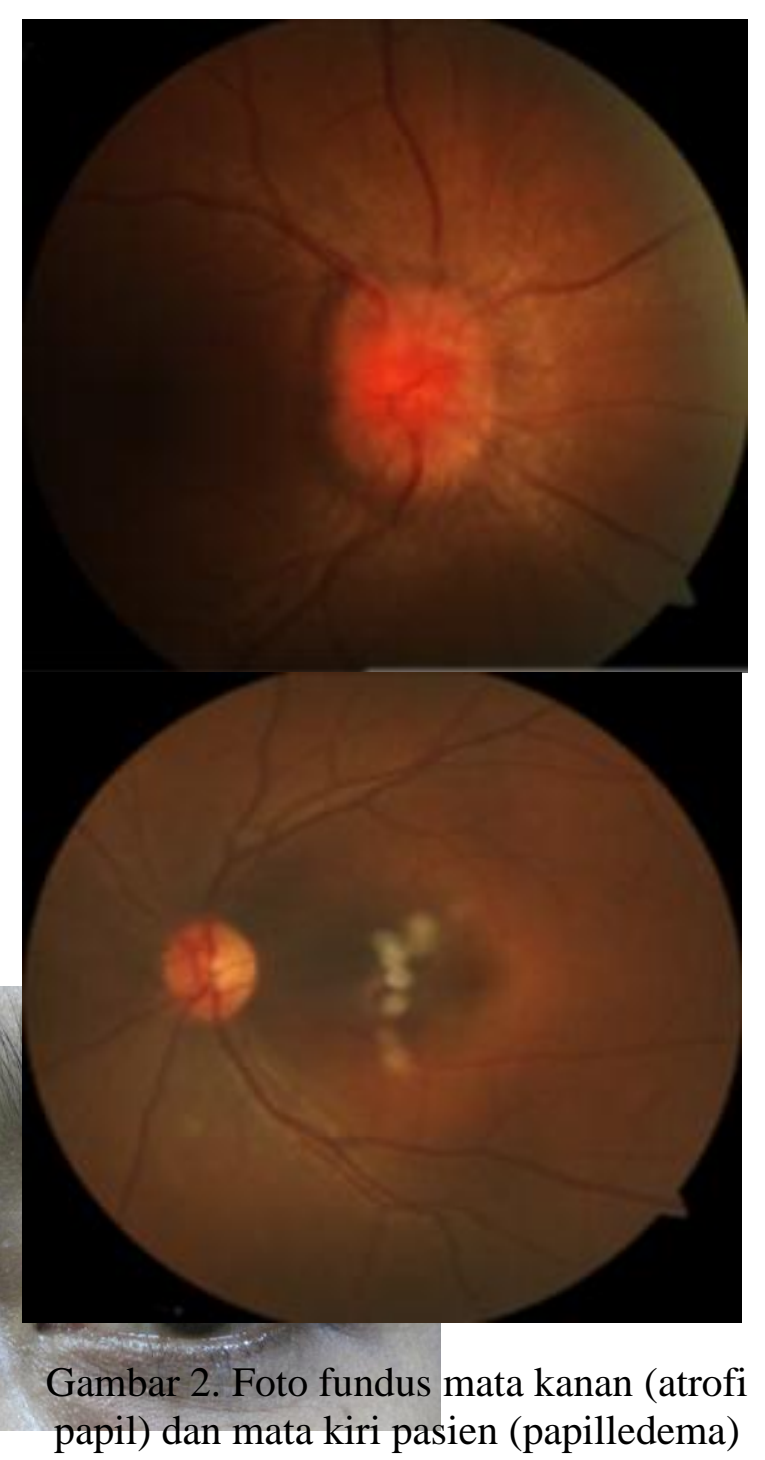

Gambar 1. Foto kondisi mata pasien saat pertama kali datang
Hasil pemeriksaan saraf-saraf kranial di dapatkan parese nervus olfaktrius yang 
ditandai hilangnya kemampuan menghidu pada cavum nasi sinistra .

Hasil pemeriksaan perimetri didapatkan, pemeriksaan lapang pandang mata kanan dan didapatkan depresi sentral berat dan skotoma absolut. Lapang pandang mata kiri di dapatkan depresi sedang dengan bintik buta melebar dan pada tes ishihara didapatkan buta warna total.

Pasien di diagnosis Sindroma Foster Kennedy et causa suspek massa intrakranial dengan diagnose banding pseudo-Foster Kennedy. Dengan dasar diagnosis adanya edema papil pada mata kanan , papil atrofi pada mata kiri dan anosmia cavum nasi sinistra. Pasien dirawat inap terkait dengan tujuan penurunan tekanan intrakranial dan upaya pelacakan penyebab penurunan visus. Pasien dirawat bersama Bagian Bedah Saraf dan dilakukan pemeriksaan laboratorium serta CT scan kepala.

Selama dirawat dibangsal pasien mendapatkan terapi : Dexamethasone Inj. $5 \mathrm{mg} / 6$ jam, Asetazolamid 250mg $3 \times 1 / 2 \mathrm{tab}$, $\mathrm{KCl} 1 \mathrm{x} 62.5 \mathrm{mg}$. Observasi pada pasien dilakukan untuk melihat adanya tanda penigkatan tekanan intrakranial. Semenjak dirawat di bangsal pasien mengaku keluhan sakit kepala berkurang dan mual muntahpun sudah tidak banyak dirasakan,

\section{Gambar 3. Gambaran CT Scan kepala tanpa kontras}

Pada pemeriksaan CT scan kepala tanpa kontras ditemukan adanya massa pada regio frontotemporalis sinistra yang mendesak sisterna ventrikel lateralis sinistra dan disertai adanya hiperostosis os temporalis sinistra.

Pasien direncanakan untuk tindakan debulking secara elektif oleh Departemen Bedah Saraf, namun pasien tidak datang kontrol. (loss follow up)

Enam bulan kemudian pasien kembali kontrol ke poli mata dengan keluhan penglihatan mata kiri gelap dan mata kanan buram . Pada anamnesis didapatkan pasien menjalani pengobatan alternatif berupa minuman herbal dan sejumlah pengobatan cara tradisional lainnya. Namun tidak mengalami perbaikan pada penglihatan. Sakit kepala pada pagi hari serta mual dan muntah masih dirasakan.

Hasil pemeriksaan mata kanan didapatkan visus 3/60 pinhole tidak maju. Palpebra dan konjungtiva tenang, kornea jernih, kamera okuli anterior dalam dan jernih, pupil bulat, central, diameter $4 \mathrm{~mm}$, reflek cahaya direk dan indirek positif. Lensa jernih, vitreus jernih, papil edema pada fase kronis atrofi, dimana papil tampak




pembuluh darah di retina, tekanan intra okular $10 \mathrm{mmHg}$. Pergerakan bola mata bebas ke segala arah dan tidak nyeri.
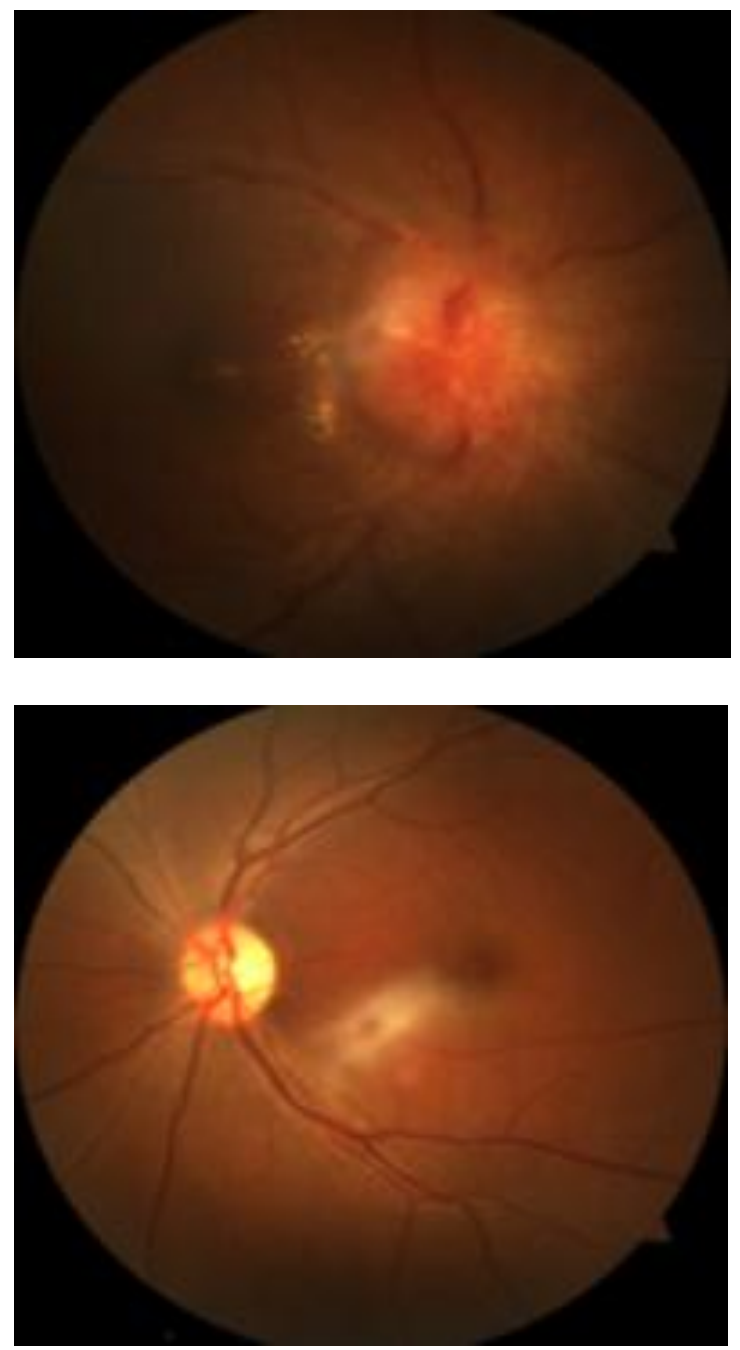

Gambar 4. Foto fundus mata kanan dan mata kiri pasien 6 bulan kemudian

Dari foto CT scan kepala dengan kontras didapatkan lesi hiperdens pada lobus temporalis dengan diameter $5 \mathrm{~cm}$ pada lobus temporalis yang mendesak dan menyempitkan kornu anterior ventrikel lateralis sinistra. Lesi hiperdens juga ditemukan pada lobus frontalis dengan diameter $1,5 \mathrm{~cm}$. Disamping itu terdapat hiperostosis alla mayor os sphenoid sinistra yang menyempitkan canalis opticus sinistra. Sehingga kesan dari gambaran CT scan merupakan sebuah meningioma sayap sphenoid dengan perluasan ke daerah sekitar.

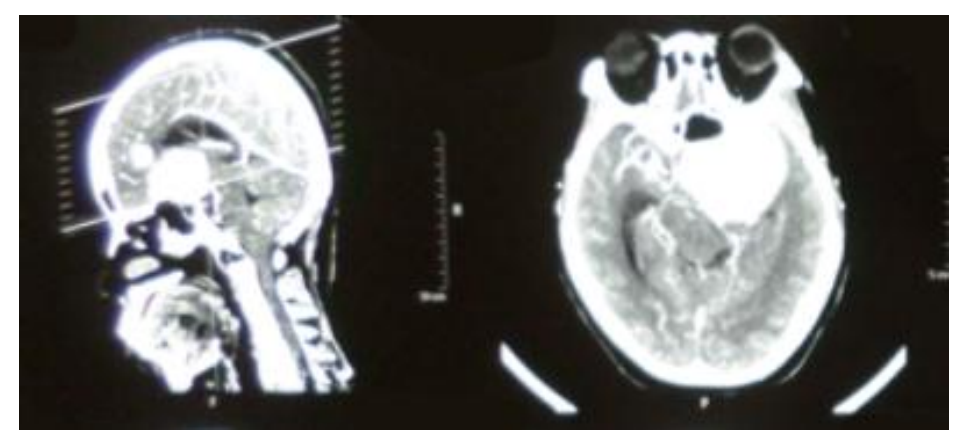

Gambar 6. CT scan

kepala dengan kontras

Pasien kemudian didiagnosis dengan OD papiledema fase kronis atrofi dan OS papil atrofi e.c massa intrakranial suspek meningioma primer. Pasien kemudian mendapat terapi asetazolamid tablet $3 \times 1$ tab, Kcl 1x1 dan observasi ketat terhadap peningkatan tekanan intrakranial. Pasien dianjurkan rawat inap dibagian bedah saraf untuk perencanaan pemasangan shunt ventriculoperitoeal namun pasien meminta waktu untuk mencari jaminan kesehatan.

\section{PEMBAHASAN}

Pada kasus ini pasien datang dengan keluhan penglihatan kedua mata terasa buram terutama mata kiri, buram terjadi perlahan-lahan, tanpa didahului kemerahan dan tidak ada nyeri di sekitar kelopak mata. Hal ini berlangsung dalam kurun waktu 4 bulan.

Pada pemeriksaan mata kanan visus masih baik dengan tampak edema diskus 
optikus,perdarahan kecil-kecil di tepi papil, vena tampak melebar dan agak hitam, reflek fovea cemerlang.

Pada pemeriksaan mata kiri didapatkan tajam penglihatan 1/60 dengan persepsi warna dan cahaya baik, terdapat pupil Marcuss Gunn, segmen posterior didapatkan papil optikus pucat, kaliber pembuluh darah retina tampak menyempit , dan reflek fovea tampak redup.

Penegakan diagnosis sindroma Foster Kennedy pada pasien ini didasarkan pada temuan:

1. Papil atrofi pada mata yang letaknya sesisi dengan posisi tumor

2. Papil edema pada mata sisi kontralateral

3. Anosmia pada sisi ipsilateral

Secara klinis terdapat 2 bentuk sindroma Foster Kennedy yaitu bentuk lengkap (complete form), bentuk tidak lengkap (incomplete form).

Bentuk lengkap (complete form) terdiri dari gambaran papil atrofi pada mata yang sesisi dengan tumor (yang disebabkan oleh penekanan langsung saraf optik bagian intrakranial) dan edema papil pada sisi mata kontralateral lesi karena peningkatan tekanan intrakranial. $2,4,5$

Bentuk tidak lengkap (incomplete form) dari sindroma ini yaitu edem papil bilateral dengan gambaran funduskopi asimetris dan perbedaan yang jelas antara kedua sisinya. Gambaran lain dari bentuk tidak lengkap sindrom ini adalah atrofi papil primer dengan skotoma sentral atau gambaran papil saraf optik normal namun terdapat skotoma sentral pada pemeriksaan lapang pandangan pada satu mata disertai gambaran papiledema pada satu mata yang lain. Gambaran lain juga dapat berupa atrofi papil edema pada satu mata dan edema papil pada mata yang lain., ${ }^{2,4.6}$

Papil atrofi merupakan suatu proses lanjut dari peyakit yang menyebabkan kerusakan permanen pada sel-sel ganglion dan akson-akson saraf optik, termasuk didalamnya akibat proses-proses iskemik, inflamasi, kompresi, infiltrasi dan demyelinisasi. Diagnosis klinis papil atrofi didasarkan pada gambaran papil yang abnormal baik warna dan struktur serta perubahan pada pembuluh darah retina dan lapisan saraf retina, gangguan fungsi visual (tajam penglihatan, penglihatan warna, pupil, lapang pandang dan visual evoked response) yang terlokalisir pada saraf optik. 5,6

Pada mata yang lain (fellow eye) didapatkan edema papil, yaitu pembengkakan papil saraf optik akibat dari pengingkatan tekanan intrakranial, dapat dijelaskan dengan patofisiologi bahwa rongga subarakhnoid otak berhubungan dengan selaput saraf optik. Oleh sebab itu bila terjadi peningkatan tekanan intrakranial, peningkatan tersebut akan diteruskan ke saraf optik menjadi tourniqet yang mengganggu transport aksoplasmik. 3,4,5 Selain mekanisme tersebut, papilledema juga dapat disebabkan oleh karena peningkatan volume jaringan oleh massa intrakranial, peningkatan volume oleh karena edema yang disebabkan oleh massa, sumbatan aliran cairan serebrospinal, gangguan drainase vena serebral dan produksi cairan serebrospinal oleh tumor itu sendiri. ${ }^{13}$

Edema papil dapat dikelompokkan menjadi 4 tipe berdasarkan klasifikasi Walsh \& Hoyt's yang pertama adalah papiledema awal yaitu hiperemi papil, pembengkakan papil, papil saraf optik batas kabur, lapisan serabut saraf retina peripapiler kabur, dan 
hilangnya pulsasi vena spontan. Kedua adalah perkembangan lengkap dimana terjadi elevasi tinggi permukaan papil saraf optik, tepi papil makin kabur, vena tampak lebih besar dan lebih hitam, perdarahan pada , tampak adanya peripapillary splinter hemorrhage dan kadang terdapat lipatan koroid, bercak ( cotton wool spot) akibat infark lokal retina, lipatan retina yang melingkar (Paton's line). Ketiga adalah edema papil kronik yaitu terjadinya perdarahan yang lebih jelas, papil saraf optik terobliterasi sempurna, hiperemi papil saraf optic berkurang, terjadi eksudat keras pada permukaan papil, dan shunt retina koroidal (Optocilliary shunt) mulai terlihat. Keempat adalah papiledema lambat (atrofi) dimana warna papil berubah pucat atau abu-abu kotor dan kabur , edema pada papil menurun, pembuluh- pembuluh darah retina menyempit, perubahan pigmentasi dan lipatan-lipatan koroid yang menetap, shunt vena retina koroidal. ${ }^{4,5,8,11}$

Kelainan pada papil saraf optik dan area peripapil akan bermanifestasi baik pada tajam penglihatan juga pada gangguan lapang pandangan yang dapat berupa altitudinal , sektoral, bowtie ataupun temporal bisa menjadi petunjuk dari pathogenesis dan lokasi lesi. ${ }^{3,4}$. Pada kasus dengan tumor pada bagian frontal seringkali juga terdapat perubahan kepribadian seperti mudah tersinggung dan labil. Sedangkan tumor pada daerah temporal sering kali memberikan gambaran defek penglihatan kontralateral superior homonymus quadrantanopia ,halusinasi visual atau pendengaran dan papilledema. ${ }^{13}$

\section{Mekanisme timbulnya sindroma Foster Kennedy}

Pada sindroma Foster Kennedy yang terjadi pada penderita tumor di lobus frontalis, massa tumor menekan secara langsung saraf optik sehingga terjadi atrofi papil karena rusaknya akson-akson sel ganglion dan atrofi sel-sel serabut saraf optik. Dengan semakin membesarnya massa maka akan menyebabkan peningkatan tekanan intraranial. Pada sisi yang mengalami papil atrofi ruang intravaginal pembungkus saraf optik telah tertutup oleh proses kompresi sehingga tidak terjadi peningkatan tekanan cairan serebrospinal dalam ruangan tersebut. Karena tidak terjadinya peningkatan tekanan cairan serebrospinal dalam pembungkus saraf optik dan atrofi dari sel-sel serabut saraf optik menjadi penghalang timbulnya edema papil pada ipsilateral lesi. Namun karena peningkatan tekanan intrakranial pada sisi kontralateral lesi dimana serabut saraf dan pembungkus saraf optik masih normal menyebabkan terjadinya edema papil. $3,7,8,10,11$

Tumor pada bagian frontal memberikan gejala perubahan kepribadian seperti mudah tersinggung dan labil. Sedangkan tumor pada daerah temporal sering kali memberikan gambaran defek penglihatan kontralateral superior homonymus quadrantanopia, halusinasi visual atau pendengaran dan papilledema. ${ }^{13}$

Beberapa tahun terakhir sindroma Foster Kennedy dikaitkan dengan gangguan hormonal pada perempuan seperti pada kasus ini. Tahun 2016 Supartoto et al, menjelaskan adanya hubungan peningkatan menginioma akibat penggunaan KB suntik (progesterone $)^{7}$. Dalam penelitian lain juga disebutkan terdapat peningkatan reseptor dari estrogen, progesterone dan reseptor androgen, namun lebih didominasi oleh reseptor progesterone. Hal ini dapat ditemukan pada $80 \%$ wanita penderita sindroma Foster Kennedy dan $40 \%$ pada pria $^{16}$. Disisi lain terdapat laporan kasus munculnya sindroma ini pada wanita hamil dengan tumor meningioma di intra kranial. ${ }^{12}$ 
Berdasar pada penemuan kasus yang terbaru ini, pada setiap gangguan saraf mata pada kecurigaan massa intrakranial sebaiknya dilakukan anamnesis yang menyeluruh terkait riwayat pemakaian $\mathrm{KB}$ maupun terapi hormonal pada pasien. Hal ini memerlukan kerjasama lintas departemen untuk memberikan tatalaksana yang sesuai.

\section{Penatalaksanaan Sindroma Foster Kennedy}

Pada pasien dengan sindroma FosterKennedy, tatalaksana utama tidak selalu berupa pengangkatan tumor. Dibutuhkan pengamatan lebih lanjut pada pasien sindroma Foster Kennedy mengenai gangguan pada drainase sinus. Pada laporan kasus yang dituliskan oleh Acebes, melakukan control tekanan intrakranial oleh karena desakan tumor menyebabkan gangguan pada drainase sinus sagital serebri memberikan hasil yang baik berupa peningkatan tajam penglihatan tidak hanya pada mata yang mengalami papilledema namun juga pada mata yang mengalami papilatrofi. ${ }^{14}$ Dalam laporan lainnya juga disebutkan bahwa perbaikan visus dapat terjadi dengan mengontrol tekanan intrakranial ${ }^{15}$

\section{Kesimpulan}

Pada kasus Sindroma Foster Kennedy yang disebabkan oleh adanya massa intrakranial, diperlukan kerjasama dalam penatalaksanaan dengan departemen lain seperti bedah saraf. Diagnosis dini dan tatalaksana pembedahan yang sesuai dapat mencegah kerusakan penglihatan lebih lanjut dan juga bertujuan "life saving".

\section{DAFTAR PUSTAKA}

1. Liu GT, Volpe NJ, Galetta SL, Neuroophthalmology : Diagnosis and Management.

Philadelphia:WB.Saunders Company 2001: $194-195$

2. Singh SR, Grewal AM, Dogra M. Foster Kennedy Syndrome. QJM : An International Journal of Medicine. 2019. Vol 0(0) : 1-2

3. Cowppli-Bony A, Bouvier G, Rué M, Loiseau H, Vital A, Lebailly $\mathrm{P}$, et al. Brain tumors and hormonal factors: review of the epidemiological literature. Cancer Causes Control 2011: 22(5):697-714

4. American Academy of Ophthalmology. Basic and Clinical Science Course. Neuro-ophthalmology. The Academy. 2010-2011. 228-232.

5. Hartono. Gangguan Gerak Mata Nuklear dan Infranuklear. Neurooftalmologi Okulomotorik \& Pupilomotorik 400 Tanya Jawab Esai. 2010. 87-100

6. Newsman SA, Arnold AC; Friedman DT,2003. Basic and Clinical Science Course Section 5.: Neuroophthalmology.American Academy of Ophthalmology. San Francisco: Palace Press:p. $141-143$.

7. Supartoto A et al. Exposure to Exogenous Female Sex Hormones is Associated with Increased Risk of Orbito-Cranial Meningioma in Females: A Case-Control Study. Int J Ophthalmic Pathol 2016:5:3

8. Supartoto et al. Relationships Between Neurofibromatosis-2, Progesterone Receptor Expression, the Use of Exogenous Progesterone, and Risk of Orbitocranial Meningioma in Females.Front Oncol 2019 :8:651

9. Lotfipour S, Chiles K, Kahn JA, Bey T, Rudkin S. An unusual presentation of subfrontal meningioma: a case report 
and literature review for Foster Kennedy syndrome. Intern Emerg Med 2011; 6:267-9.

10. Miller NR, Newman NJ. The Essentials : Walsh\&Hoyt's Clinical NeuroOphthalmology. $5^{\text {th }}$ ed. Philadelphia: Lippincott Williams\& Wilkins,1999: 76-83:146-150.

11. Lindsay KW,Bone I.1997.Neurology and Neurosurgery Illustrated. $3^{\text {rd }}$ edition. London: Churchill Livingston,pp.74- 80; 297-325.

12. Porcel FR, Hughes I, Anderson D, Lee J, Biller J. Foster Kennedy syndrome due to meningioma growth during pregnancy. Front Neurol.2013 :4(18);13

13. Kaye A, R. Laws E. Brain tumors. 3rd ed. W.B. Saunders; 2012.

14. Acebes X, Arruga J, Acebes J, Majos C, Muñoz S, Valero I. Intracranial Meningiomatosis Causing Foster Kennedy Syndrome by Unilateral Optic Nerve Compression and Blockage of the Superior Sagittal Sinus. Journal of Neuro-Ophthalmology. 2009;29(2):140142.

15. Pastora-Salvador N, Peralta-Calvo J. A letter from CMAJ' s Editorial Advisory Board. Canadian Medical Association Journal [Internet]. 2016;188(10):754.1754. Available from: https://www.cmaj.ca/content/cmaj/183/ 18/2135.full.pdf

16. Vadivelu S, Sharer L, Schulder M. Regression of multiple intracranial meningiomas after cessation of longterm progesterone agonist therapy. Journal of Neurosurgery [Internet]. 2010 [cited 22 November 2020];112(5):920-924. Available from: https://thejns.org/view/journals/jneurosurg/112/5/article-p920.xml 